\title{
Risks Leading to Cost Overrun in Building Construction from Consultants' Perspective
}

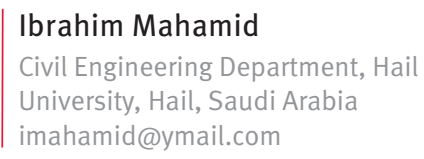

\author{
Nabil Dmaidi \\ Civil Engineering Department, \\ An-Najah National University, Nablus, \\ Palestine. and Minister of transport, \\ Palestinian ministry of transportation \\ pa@najah.edu
}

DOI 10.5592/otmcj.2013.2.5

Research paper

\section{Keywords}

Cost Overrun,

Risk Map, Building

Construction, Construction in Palestine
THIS STUDY AIMS AT IDENTIFYING THE RISK MAP FOR FACTORS AFFECTING COST OVERRUN IN BUILDING CONSTRUCTION PROJECTS IN THE West Bank in Palestine from the consultants' Perspective. The field survey included 26 consultants. 41 factors are identified through literature review. The factors are divided into 5 groups. The analysis of the identified 41 factors indicates that 1 factor is located in the green zone, 14 factors are located in the yellow zone, and 26 factors are located in the red zone of the risk map. The results indicate that the top five affecting factors are: political situation, fluctuation of prices of materials, economic instability, currency exchange, and level of competitors. It is hoped that these findings will guide efforts to enhance the cost performance of construction industry. 


\section{INTRODUCTION}

The construction industry is the tool through which society goals of urban and rural development can be achieved. It has a great impact on the economy of all countries (Leibing, 2001). However, the construction process is influenced by highly changing and unexpected variables, which could result from different sources. These sources include performance of construction parties, financial issues, managerial issues, resources unavailability, and external conditions. As a result, poor performance in terms of delay and cost overrun in construction projects could occur. The construction industry and its parties are associated with high degree of risk due to the nature of construction business activities, processes, environment and organization. Risk in construction has been the object of attention because of time and cost overruns associated with construction projects (Kartam et al., 2001).

Cost overrun is one of the most important problems in the construction. According to Azhar et al. (2008), cost overrun is a very frequent phenomenon and is almost associated with all projects of construction industry. Cost overrun is simply defined as the difference between the final actual cost of a construction project at completion and the contract amount, agreed by and between the owner and the contractor during signing of the contract. According to Ahmed et al. (2003), cost overrun and delays on construction projects are a universal phenomenon. "They have a negative effect on clients, contractors, and consultants in terms of growth in adversarial relationships, mistrust, litigation, arbitration, cashflow problems, and a general feeling of trepidation towards each other" (Ahmed et al., 2003). So it is essential to define the actual causes of cost overrun in order to minimize and avoid increasing cost in any construction project and to avoid any other negative effects.

In Palestine, the construction sector contributes to $26 \%$ of the Palestinian GDP (MAP, 2002). This is a relatively high proportion covered by this sector comparing to what is mentioned by Chitkara (2004) in that construction industry accounts 6-9 \% of GDP in many countries, thus it strongly affecting various economic, social, educational, and vocational sectors.

Palestinian construction sector plays a major role in supporting the Palestinian national economy, providing homes and facilities, improving infrastructure, and absorption labor forces. However, many local construction projects report poor performance due to many causes such as (UNRWA 2006):

$\checkmark$ unavailability of materials

- excessive amendments of design and drawings

$>$ poor coordination among participants

$\checkmark$ ineffective monitoring and feedback

> lack of project leadership skills

While the observations indicate that the cost overrun is a major phenomenon in Palestinian construction industry, very few studies have been conducted to investigate it. This paper presents the findings of a survey aims at identifying the risk map for factors affecting cost overrun in building construction projects in the West Bank in Palestine from the consultants' perspective. It is hoped that these findings will guide efforts to enhance the performance of the construction industry in Palestine.

\section{Objectives}

The objectives of this paper include the following:

To identify the factors affecting cost overrun in building construction in the West Bank in Palestine from consultants' perspective

To identify the risk map for cost overrun factors

\section{Literature review}

Numbers of studies have been conducted to investigate the cost overrun in construction projects. Mahamid et al. (2012) conducted a study to investigate the statistical relationship between actual and estimated cost of road construction projects using data from Palestinian road construction projects awarded over the years 2004 to 2008 . The study was based on a sample of 169 road construction projects. The findings reveal that $100 \%$ of projects suffer from cost diverge, it is found that $76 \%$ of projects have cost under estimation and $24 \%$ have cost over estimation. The discrepancy between estimated and actual cost has average of $14.56 \%$, ranging from $-39.3 \%$ to $98 \%$.

Al-Zarooni et al. (2000) conducted a survey to investigate variations in UAE public projects' estimates. They found that the variations (positive or negative) between feasibility and contract cost, ranging between $-28.5 \%$ and $+36 \%$. They stated that these variations could be explained by the fact that feasibility estimates in the government agencies are usually budgeted using a Single Unit Estimating (cost per square foot) basis, regardless of the nature of projects and their associated risks or the construction complexity of each building type.

Researches on construction projects in some developing countries indicated that by the time a project is completed, the actual cost exceeds the original contract price by about $30 \%$ (Al-Momani, 1996).

Odeck et al. (1995) assessed Norwegian toll roads in order to reveal whether planning procedure shortcomings experienced by Norwegian road agencies had resulted in poorer than projected financial performances for some of the toll roads. They found overestimation of traffic forecasts and underestimation of construction costs. In their small sample of 12 toll projects, they found cost overruns on average at about $5 \%$, but the interval was large from -210 to $170 \%$. 


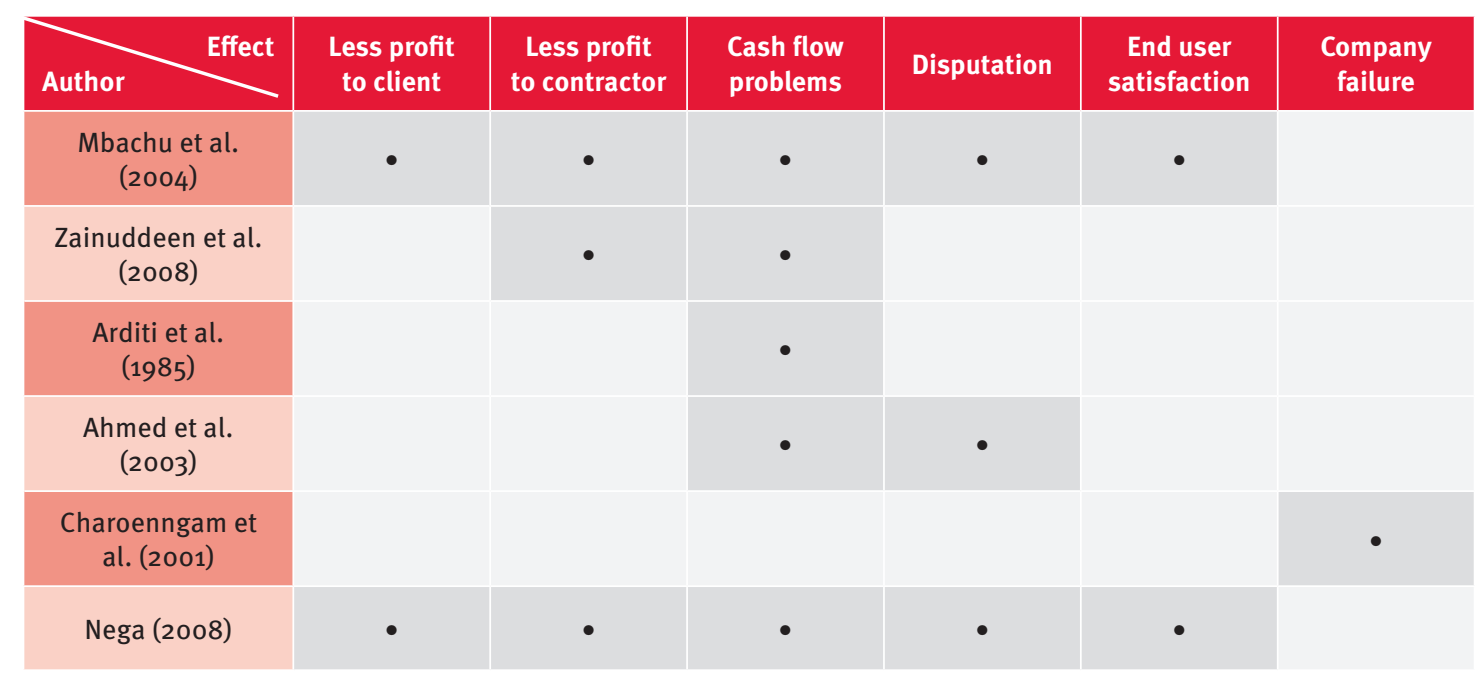

Table 1. Main effects of cost overrun in construction projects through previous studies

Al-Juwairah (1997) conducted a study to identify the most severe factors affecting construction cost in Saudi Arabia. 42 factors were considered in the study. He concluded that the most severe factors affecting construction cost from the contractors' perspective are: cost materials, incorrect planning, contract management, wrong estimation method, and previous experience in contract.

Al-khaldi (1990) concluded that the top five factor affecting construction cost in Saudi Arabia from contractors' view are previous experience in contracts, payments, availability of management finance and plans, type and size of contract and its content, and project location. On the other hand, the top five factors from consultants view are previous experience of contract, type and size of contract and its content, payments, project location, and contract period.

Al-Najjar (2008) identified the essential factors and their relative importance that affect cost overrun in construction projects in the Gaza strip. The study illustrated that the top affecting factors include: prices fluctuations of constructions, contractor's delay of material delivery and equipment, and prices inflation.

lyer et al. (2005) conducted a study to identify the factors affecting cost performance of Indian construction projects. 55 factors were identified. They concluded that the top affecting factors are: conflict among project participants, ignorance and lack of knowledge, presence of poor project specific attributes and non existence of cooperation, hostile socio- economic and climatic conditions, reluctance in timely decision, aggressive competition at tender stage and short bid preparation time.

Elinwa et al. (1993) identified 31 factors affecting the construction cost in Nigerian Construction projects. They concluded that cost of materials, fraudulent practices and kickbacks, and fluctuation of prices of materials are three of the most important factors leading to cost overrun.

Frimpong et al. (2003) concluded that the main causes of delay and cost overruns in construction of groundwater projects in Ghana are: monthly payment difficulties from agencies, poor contractor management, material procurement, poor technical performances, and escalation of material prices.

Azhar et al. (2008) conducted a study in order to identify the major cost overrun factors in construction projects in Pakistan. 42 factors were identified. They found that the top ten affecting factors are: fluctuation in prices of raw materials, unstable cost of manufactured materials, high cost of machineries, lowest bidding procurement procedures, poor project (site) management or poor cost control, delays between design and procurement phases, incorrect or inappropriate methods of cost estimation, additional work, improper planning, and unsupportive government policies.

Okpala et al. (1988) studied the causes of delay and cost overrun in construction projects in Nigeria. 20 factors were identified as causes of delay and 27 factors as causes of cost overrun. The results indicated the following:

1. "high costs can be minimized by minimizing lapses in the management of human and material resources.

2. despite some slight differences, the professionals generally agreed that shortage of materials, methods of financing and payments for completed works, and poor contract management are the three major reasons for high construction costs.

3. price fluctuation (in material) was identified as the most important factor responsible for the escalation of project costs."

Nega (2008) found that the most important causes of cost overrun in building construction projects in Ethiopia are inflation or increase in the cost of construction materials, poor planning and coordination, change orders due to enhancement required by clients, and excess quantity during construction. 
1) Cost estimating factors

cost of labor

cost of machinary

transportation cost

high machinary maintenace cost

high interest rates by bankers

wrong estimation method

cost of insurance

fluctuation of prices of materials

bureaucracy in tendering method

waste on site

long period between design and time of tendering

2) Factors related to construction items

fraudulent practices and kickbacks

contract management

additional work

duration of contract period

contractual procedure

frequent changes in design

lack of adequate manpower

3) Factors related to project participants

disputes on site

lack of coordination between construction parties

poor financial control on site

poor planning

previous experience of contract

relationship between managers and labors

4) Environmental factors

level of competitors

manipulation of suppliers

absence of construction-cost data

economic instability

effects of weather

government policies

inadequate production of raw materials by the country

monopoly by suppliers

number of competitors

number of projects going at the same time

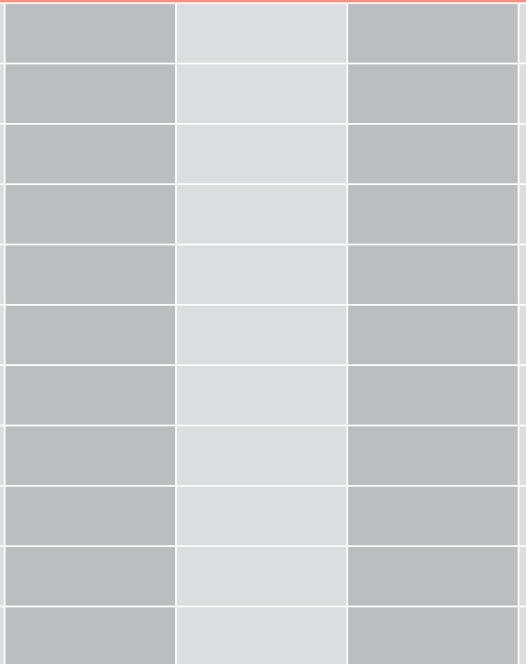

\begin{tabular}{|l|}
\hline \\
\hline \\
\hline \\
\hline \\
\hline \\
\hline \\
\hline \\
\hline \\
\hline \\
\hline
\end{tabular}
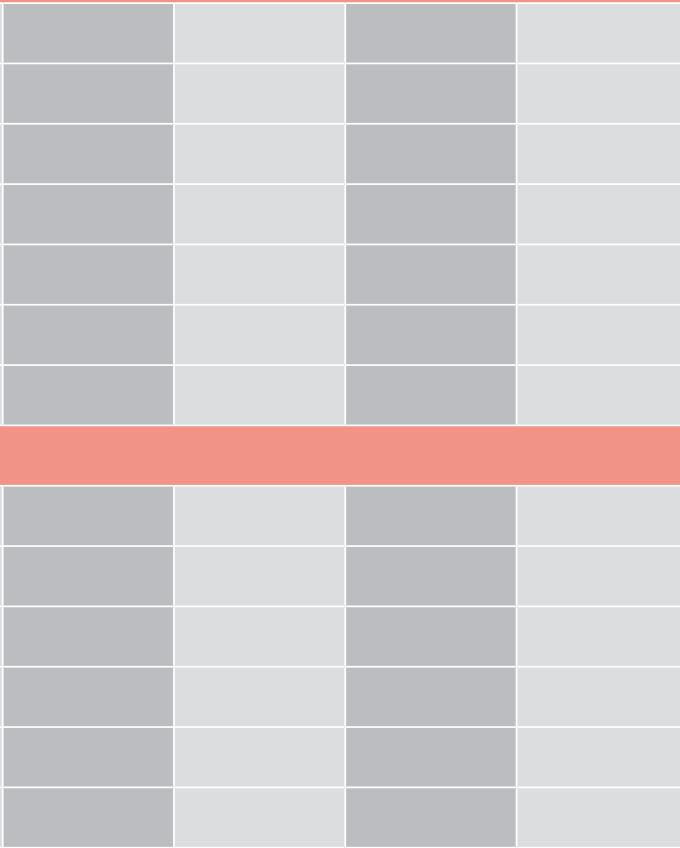


\begin{tabular}{|l|l|l|l|}
\hline political situation & \\
\hline poor productivity & & \\
\hline project location & & \\
\hline social and cultural impacts & & \\
\hline 5) Financing factors & & \\
\hline currency exchange & & \\
\hline inflationary pressure & \\
\hline project financing & & \\
\hline
\end{tabular}

Table 2. List of cost overrun factors

A number of studies were conducted to investigate the effects of cost overrun in construction projects. Table 1 summarizes some of these effects as presented in some previous studies.

\section{Research methodology}

41 factors that might affect cost overrun in building construction projects were defined through a detailed literature review. The similar factors were grouped under one main group; the factors were divided into 5 groups: cost estimating, construction items, project participants, environmental, and financing (Table 2). The factors were tabulated into a questionnaire form. Then the draft questionnaire was discussed with some construction parties who are involved in building construction to evaluate the content of the questionnaire. Modifications and changes have been done. Recommendations for minimizing cost overrun in building construction projects were emphasized in view of the results of the study.

\section{Questionnaire design}

The questionnaire is divided into two main parts. Part I is related to general information for the company. The consultants were requested to answer questions pertaining to their experience in building construction and their opinions about the percentage average cost overrun in building construction projects they have experienced. Part II includes the list of the identified factors affecting cost overrun in building construction. For each factor two questions were asked: what is the degree of severity of this factor on cost overrun in building construction? And what is the frequency of occurrence for this factor? Both frequency and severity were categorized on a five-point scale as follows: very high, high, moderate, little and very little (on 5 to 1 point scale).

\section{Data analysis}

Frequency index (F.I) and severity index (S.I) are calculated for each factor according to the following formula

\begin{tabular}{|c|c|c|}
\hline Index value (Scale) & Severity & Frequency \\
\hline$\leq 20 \%$ & very low $(\mathrm{VL})$ & very low $(\mathrm{VL})$ \\
\hline $20 \%-40 \%$ & low $(\mathrm{L})$ & low $(\mathrm{L})$ \\
\hline $40 \%-60 \%$ & moderate $(\mathrm{M})$ & moderate $(\mathrm{M})$ \\
\hline $60 \%-80 \%$ & high $(\mathrm{H})$ & high $(\mathrm{H})$ \\
\hline $80 \%-100 \%$ & very high $(\mathrm{VH})$ & very high $(\mathrm{VH})$ \\
\hline
\end{tabular}

Table 3. Scale used to identify factor's severity and frequency level

Index $(\%)=\Sigma a(n / N) \square 100 / 5$ (1)

Where; $a$ is the constant expressing weighting given to each response (ranges from 1 for very low up to 5 for very high)

$\mathrm{n}$ is the frequency of the responses $\mathrm{N}$ is total number of responses

Table 3 shows the scale used to determine the severity and frequency levels for cost overrun factors. When the factor's severity and frequency levels are calculated, its location in the risk map is identified according to Figure 1 and Table 4.

Figure 1 and Table 4 show the standard risk map which is used to determine the risk zone for each identified cost overrun factor. The map is $5 \times 5$ matrix with severity ranging from $V L$ to VH on the horizontal axis and frequency (with the same range) on the vertical axis. Three zones are presented in the map: green, yellow and red (The U.S. Federal Highway Administration Office of International Programs, 2007).

The zones have the following characteristics:

Green zone: risks in this zone are low level, and can be ignored.

Yellow zone: risks in this zone are of moderate importance; if these things happen, one can cope with them and move on. However, if their frequency is moderate it should be reduced and if their severity is moderate, it should be controlled and reduced and a contingency plans should be in place just in case they do. 


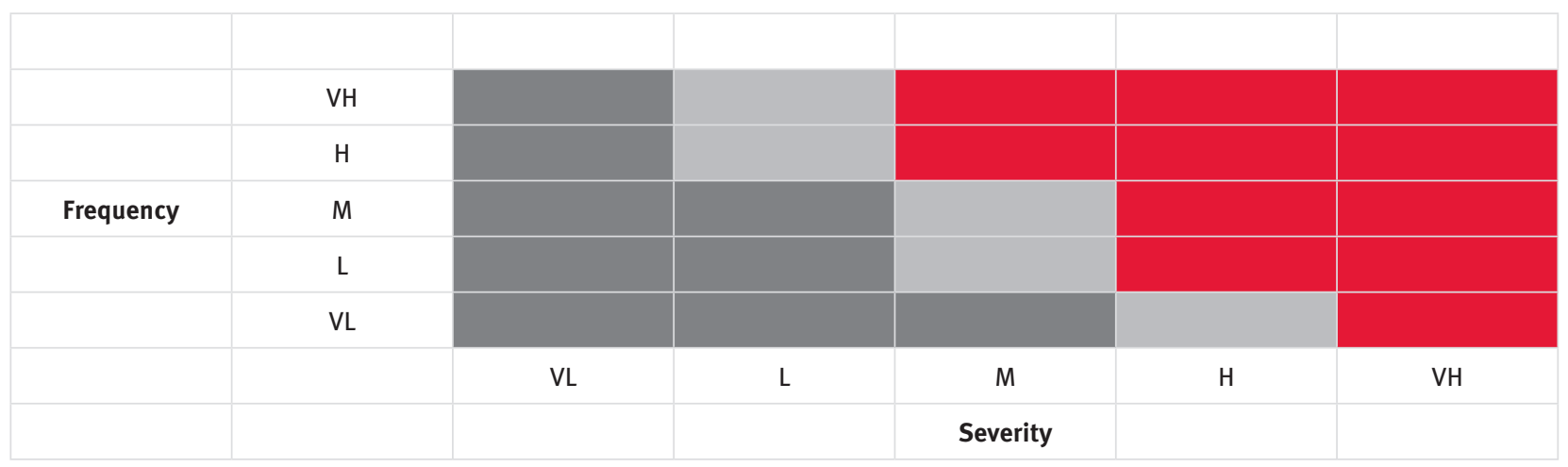

Figure 1. Zones of the risk map

Red zone: risks in this zone are of critical importance. These are the top priorities, and are risks that a close attention should be paid to them.

\section{Results and findings of the research}

\section{General characteristics of} respondents

The questionnaire was sent out to a total of 30 consultants, asking their contribution in identifying the risk map for the considered 41 factors in terms of severity and frequency using an ordinal scale. A total of 26 consultants filled the questionnaire. The response rate by the consultants is $87 \%$.

Figure 2 shows the distribution of the respondents according to their experience in building construction. It shows that most of respondents have experience of more than 15 years in building construction.

\begin{tabular}{|c|c|c|c|c|c|}
\hline $\begin{array}{c}\text { Severity } \\
\text { Frequency }\end{array}$ & VL & L & M & H & VH \\
\hline VL & green & green & green & yellow & red \\
\hline L & green & green & yellow & red & red \\
\hline $\mathbf{M}$ & green & green & yellow & red & red \\
\hline $\mathbf{H}$ & green & yellow & red & red & red \\
\hline $\mathbf{V H}$ & green & yellow & red & red & red \\
\hline
\end{tabular}

Table 4. The risk map

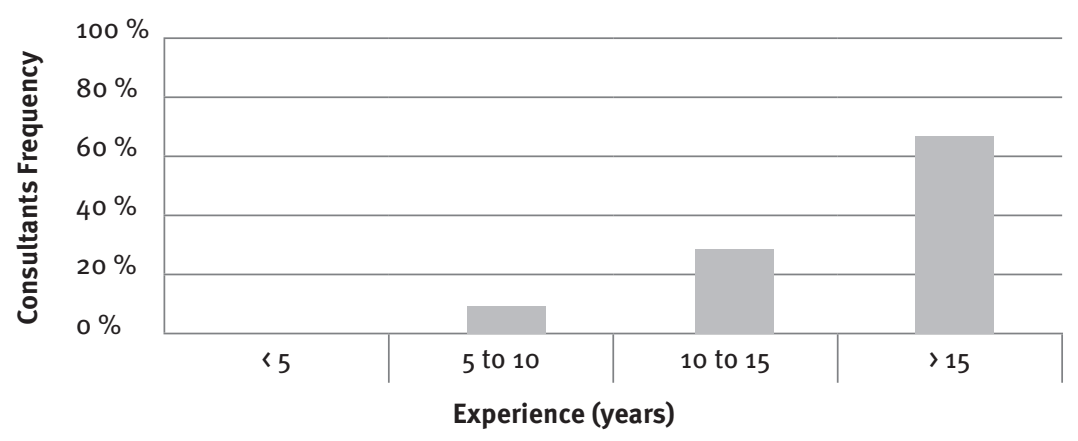

Figure 2. Distribution of the respondents according to their experience in building construction

Size of cost overrun in building construction projects

The analysis of the participants' responses regarding the cost overrun in building construction projects reveals that $100 \%$ of respondents indicated that the average cost overrun in building construction projects that they have experienced is between $10 \%$ and $30 \%$ of the original estimated cost of a project. More illustration is shown in Figure 3.

\section{Factors' risk map}

\section{Cost estimating factors}

Table 5 and Figure 4 illustrate the risk map for cost estimating factors. 11 factors are considered under this group. The results indicate that 4 factors are located in the red zone, 6 factors are located in the yellow zone and 1 factor is located in the green zone.

Factors related to construction items Table 6 and Figure 5 illustrate the risk map for factors related to construction items. 7 factors are identified under this group. The results indicate that 5 factors are located in the red zone and 2 factors are located in the yellow zone. The table shows that there is no factor under this group is located in the green zone.

Factors related to project participants Table 7 and Figure 6 illustrate the risk map for factors related to project participants. 6 factors are considered under this group. The results indicate that all factors under this group are located in the red zone. 


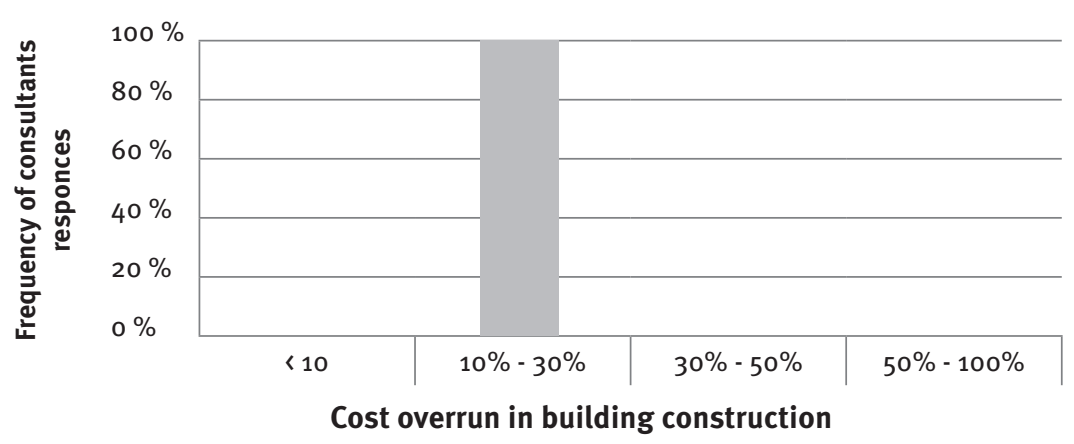

Figure 3. Responses regarding the average cost overrun in building construction

\section{Environmental factors}

Table 8 and Figure 7 show the risk map for environmental factors. 14 factors are identified under this group. The results indicate that 8 factors are located in the red zone and 6 factors are located in the yellow zone.

\section{Top affecting factors}

Table 10 shows the top priority factors that affecting cost overrun in building construction projects and their related groups in ascending order. All of these factors are located in the red zone of the risk map. In order to rank them according to their degree of importance from consultants' perspective, the importance index for each factor is calculated as a function of frequency and severity indexes, as follows:

Importance Index (IMP.I) (\%) = [(F.I) (\%) $\square(\mathrm{S} . \mathrm{I})(\%)] / 100$ (2)

The results indicate that there are 26 factors located in the critical zone of the risk map. Their distribution among the groups is as follow:

Table 9 and Figure 8 illustrate the risk map for financing factors. 3 factors are considered under this group. The results indicate that all factors under this group are located in the red zone. $\checkmark 4$ factors are related to cost estimating

5 factors are related to construction items

\begin{tabular}{|c|c|c|c|c|c|}
\hline Factor & S.I & Severity level & F.I & $\begin{array}{l}\text { Frequency } \\
\text { level }\end{array}$ & Map zone \\
\hline cost of labor & 59.62 & M & 57.69 & M & yellow \\
\hline cost of machinary & 54.81 & M & 47.12 & M & yellow \\
\hline transportation cost & 50.96 & M & 50.00 & M & yellow \\
\hline high machinary maintenace cost & 44.23 & M & 50.00 & M & yellow \\
\hline high interest rates by bankers & 44.23 & M & 45.19 & M & yellow \\
\hline wrong estimation method & $65 \cdot 38$ & H & 58.65 & M & red \\
\hline cost of insurance & 44.23 & M & 46.15 & M & yellow \\
\hline fluctuation of prices of materials & 81.73 & VH & 77.88 & H & red \\
\hline bureaucracy in tendering method & 63.46 & $\mathrm{H}$ & 49.04 & M & red \\
\hline waste on site & 32.69 & $\mathrm{~L}$ & 50.00 & $M$ & green \\
\hline $\begin{array}{c}\text { long period between design and time of } \\
\text { tendering }\end{array}$ & 60.58 & H & 56.73 & $M$ & red \\
\hline
\end{tabular}

Table 5. Risk map for cost estimating factors

\begin{tabular}{|l|l|l|}
\hline waste on site & $\begin{array}{l}\text { cost of labor } \\
\text { cost of machinary } \\
\text { transportation cost } \\
\text { cost of insurance } \\
\text { high machinary maintenace cost } \\
\text { high interest rates by bankers }\end{array}$ & $\begin{array}{l}\text { wrong estimation method } \\
\text { fluctuation of prices of materials } \\
\text { bureaucracy in tendering method } \\
\text { long period between design and time } \\
\text { of tendering }\end{array}$ \\
& \\
\hline
\end{tabular}

Figure 4. Risk map for cost estimating factors 


\begin{tabular}{|c|c|c|c|c|c|}
\hline Factor & S.I & Severity level & F.I & $\begin{array}{c}\text { Frequency } \\
\text { level }\end{array}$ & Map zone \\
\hline fraudulent practices and kickbacks & 54.81 & M & 49.04 & M & yellow \\
\hline contract management & 74.04 & H & 66.35 & H & red \\
\hline additional work & 54.81 & M & 59.62 & M & yellow \\
\hline duration of contract period & 68.27 & H & 62.50 & H & red \\
\hline contractual procedure & 59.62 & M & 60.58 & H & red \\
\hline frequent changes in design & 66.35 & H & 55.77 & M & red \\
\hline lack of adequate manpower & 64.42 & $\mathrm{H}$ & 50.96 & M & red \\
\hline
\end{tabular}

Table 6. Risk map for factors related to construction items

\begin{tabular}{|c|c|c|}
\hline $\begin{array}{c}\text { fraudulent practices and kickbacks } \\
\text { additional work }\end{array}$ & $\begin{array}{c}\text { lack of adequate manpower } \\
\text { duration of contract period } \\
\text { contractual procedure } \\
\text { frequent changes in design } \\
\text { contract management }\end{array}$ \\
\hline
\end{tabular}

Figure 5. Risk map for factors related to construction items

\begin{tabular}{|c|c|c|c|c|c|}
\hline Factor & S.I & Severity level & F.I & $\begin{array}{l}\text { Frequency } \\
\text { level }\end{array}$ & Map zone \\
\hline disputes on site & 63.46 & $\mathrm{H}$ & 55.77 & M & red \\
\hline $\begin{array}{l}\text { lack of coordination between construction } \\
\text { parties }\end{array}$ & $67 \cdot 31$ & H & 54.81 & M & red \\
\hline poor financial control on site & 62.50 & H & 53.85 & M & red \\
\hline poor planning & 80.77 & VH & 58.65 & M & red \\
\hline previous experience of contract & 78.85 & H & $67 \cdot 31$ & H & red \\
\hline relationship between managers and labors & 62.50 & H & 64.42 & H & red \\
\hline
\end{tabular}

Table 7. Risk map for factors related to project participants

\begin{tabular}{|c|c|}
\hline & disputes on site \\
& lack of coordination between designers and contractors \\
poor financial control on site \\
poor planning \\
previous experience of contract \\
relationship between managers and labors
\end{tabular}

Figure 6. Risk map for factors related to project participants

6 factors are related to construction parties

8 factors are related to environmental group

3 factors are related to financing group

It can be seen that all factors related to construction parties are identified as critical factors. These factors are human related, meaning that these factors could be controlled and reduced by improving the skills of the participants (i.e. contractors, consultants, designers, owners, labors, and suppliers). The results are supported by some investigated previous studies as shown in Table 11.

\section{Statistical analyses}

Tables 12 presents the statistical analyses for the severity and frequency responses of cost overrun factors as assessed by consultants. The table contains the computation of the weighted mean, standard deviation, and coefficient of variation. These statistics are used to interpret the dispersion, 


\begin{tabular}{|c|c|c|c|c|c|}
\hline Factor & S.I & Severity level & F.I & $\begin{array}{l}\text { Frequency } \\
\text { level }\end{array}$ & Map zone \\
\hline level of competitors & 75.00 & $\mathrm{H}$ & 72.12 & $\mathrm{H}$ & red \\
\hline manipulation of suppliers & 76.92 & $\mathrm{H}$ & 60.58 & $\mathrm{H}$ & red \\
\hline absence of construction-cost data & 58.65 & M & 58.65 & M & yellow \\
\hline economic instability & 80.77 & VH & 68.27 & $\mathrm{H}$ & red \\
\hline effects of weather & 58.65 & M & 49.04 & M & yellow \\
\hline government policies & 54.81 & M & 48.08 & M & yellow \\
\hline $\begin{array}{l}\text { inadequate production of raw materials by the } \\
\text { country }\end{array}$ & 69.23 & $\mathrm{H}$ & 51.92 & M & red \\
\hline monopoly by suppliers & 55.77 & M & 39.42 & $\mathrm{~L}$ & yellow \\
\hline number of competitors & 73.08 & $\mathrm{H}$ & 73.08 & $\mathrm{H}$ & red \\
\hline number of projects going at the same time & 63.46 & $\mathrm{H}$ & $55 \cdot 77$ & M & red \\
\hline political situation & 87.50 & VH & 76.92 & $\mathrm{H}$ & red \\
\hline poor productivity & 58.65 & M & 56.73 & M & yellow \\
\hline project location & $65 \cdot 38$ & $\mathrm{H}$ & 52.88 & M & red \\
\hline social and cultural impacts & 48.08 & M & 48.08 & M & yellow \\
\hline
\end{tabular}

Table 8. Risk map for environmental factors

\begin{tabular}{|l|l|l|}
\hline & $\begin{array}{l}\text { absence of construction-cost data } \\
\text { effects of weather } \\
\text { government policies } \\
\text { monopoly } \\
\text { poor productivity } \\
\text { social and cultural impacts }\end{array}$ & $\begin{array}{l}\text { level of competitors } \\
\text { manipulation of suppliers } \\
\text { economic instability } \\
\text { inadequate production of raw materials by } \\
\text { the country } \\
\text { number of competitors } \\
\text { number of projects going at the same time } \\
\text { political situation } \\
\text { project location }\end{array}$ \\
\hline
\end{tabular}

Figure 7. Risk map for environmental factors

\begin{tabular}{|c|c|c|c|cc|c|}
\hline Factor & S.I & Severity level & F.I & $\begin{array}{c}\text { Frequency } \\
\text { level }\end{array}$ & Map zone \\
\hline currency exchange & 73.08 & H & 74.04 & H & red \\
\hline inflationary pressure & 77.88 & H & 66.35 & H & H & red \\
\hline project financing & 75.96 & H & 68.27 & H
\end{tabular}

Table 9. Risk map for financing factors

\begin{tabular}{|l|l|}
\hline & $\begin{array}{l}\text { currency exchange } \\
\text { inflationary pressure } \\
\text { project financing }\end{array}$ \\
\hline
\end{tabular}

Figure 8. Risk map for financing factors 


\begin{tabular}{|c|c|c|c|c|c|c|}
\hline Factor & S.I & $\begin{array}{c}\text { Severity } \\
\text { level }\end{array}$ & F.I & Frequency level & IMP.I & Related group \\
\hline political situation & 87.50 & VH & 76.92 & $\mathrm{H}$ & 67.31 & environmental \\
\hline fluctuation of prices of materials & 81.73 & VH & 77.88 & H & 63.66 & cost estimating \\
\hline economic instability & 80.77 & VH & 68.27 & $\mathrm{H}$ & 55.14 & environmental \\
\hline currency exchange & 73.08 & H & 74.04 & H & 54.11 & financing \\
\hline level of competitors & 75.00 & H & 72.12 & $\mathrm{H}$ & 54.09 & environmental \\
\hline number of competitors & 73.08 & H & 73.08 & $\mathrm{H}$ & 53.40 & environmental \\
\hline previous experience of contract & 78.85 & $\mathrm{H}$ & 67.31 & H & 53.07 & project participants \\
\hline project financing & 75.96 & $\mathrm{H}$ & 68.27 & $\mathrm{H}$ & 51.86 & financing \\
\hline inflationary pressure & 77.88 & H & 66.35 & H & 51.67 & financing \\
\hline contract management & 74.04 & H & 66.35 & H & 49.12 & construction items \\
\hline poor planning & 80.77 & VH & 58.65 & M & 47.37 & project participants \\
\hline manipulation of suppliers & 76.92 & H & 60.58 & H & 46.60 & environmental \\
\hline duration of contract period & 68.27 & $\mathrm{H}$ & 62.50 & H & 42.67 & construction items \\
\hline relationship between managers and labors & 62.50 & $\mathrm{H}$ & 64.42 & $\mathrm{H}$ & 40.26 & project participants \\
\hline wrong estimation method & 65.38 & $\mathrm{H}$ & 58.65 & M & 38.35 & cost estimating \\
\hline frequent changes in design & 66.35 & H & 55.77 & M & 37.00 & construction items \\
\hline $\begin{array}{l}\text { lack of coordination between construction } \\
\text { parties }\end{array}$ & 67.31 & H & 54.81 & M & 36.89 & project participants \\
\hline contractual procedure & 59.62 & M & 60.58 & $\mathrm{H}$ & 36.11 & construction items \\
\hline $\begin{array}{l}\text { inadequate production of raw materials by the } \\
\text { country }\end{array}$ & 69.23 & $\mathrm{H}$ & 51.92 & M & 35.95 & environmental \\
\hline disputes on site & 63.46 & H & 55.77 & M & 35.39 & project participants \\
\hline number of projects going at the same time & 63.46 & $\mathrm{H}$ & $55 \cdot 77$ & M & $35 \cdot 39$ & environmental \\
\hline project location & $65 \cdot 38$ & H & 52.88 & M & 34.58 & environmental \\
\hline $\begin{array}{l}\text { long period between design and time of } \\
\text { tendering }\end{array}$ & 60.58 & $\mathrm{H}$ & 56.73 & M & $34 \cdot 37$ & cost estimating \\
\hline poor financial control on site & 62.50 & $\mathrm{H}$ & 53.85 & M & 33.65 & project participants \\
\hline lack of adequate manpower & $64 \cdot 42$ & H & 50.96 & M & 32.83 & construction items \\
\hline bureaucracy in tendering method & 63.46 & H & 49.04 & M & 31.12 & cost estimating \\
\hline
\end{tabular}

Table 10. Red zone factors and their related groups

compactness, and the degree of homogeneity of the collected data

Table 12 shows that the standard deviations of the cost overrun factors for severity and frequency responses are ranging from 0.55 to 1.24 and 0.63 to1.06, respectively. A visual indication obtained from the scatter diagram shown in Figure 9 and Figure 10 shows that the data has good compactness, indicating that there is a good data consistency and agreement between consultants on the severity and frequency of the identified factors.

Table 12 also shows that the statistical analyses of the severity and frequency responses have reasonable coefficient of variations, ranging from $15 \%-40 \%$ and $16 \%-43 \%$ respectively.
Visually, it can be seen from Figure 11 and Figure 12 that as the factors weighted mean increase, the coefficient of variation decrease, meaning that the participants are highly agreed on the impact of the top affecting factors. 
Political situation

Fluctuation of prices of materials

Level of competitors

Previous experience of contract

Project financing

Inflationary pressure

Contract management

Poor planning

Duration of contract period

Wrong estimation method

Frequent changes in design

Lack of coordination between construction parties

Contractual procedure

Inadequate raw materials

Project location

Poor financial control on site

Long period between design and time of tendering

Table 11. Comparison between findings of this study and previous studies

\section{Conclusion}

This study is conducted to investigate the cost overrun in Palestinian building construction projects from consultants' perspective through a questionnaire survey. The analysis of the participants' responses reveals that the cost overrun in building construction projects is a severe problem. $100 \%$ of the respondents indicated that the average cost overrun that they have experienced is between $10 \%$ and $30 \%$ of the project's estimated cost. The study also identified the risk map for 41 cost overrun factors. 26 factors were concluded as critical factors. Inputs of the consultants underline that the top five factors affecting cost overrun in building construction projects are: political situation, fluctuation of prices of materials, level of competitors, currency exchange, and economic instability.

The statistical analyses of the severity and frequency responses indicate that the data has good compactness and homogeneity, meaning that there
Al-Najjar (2008)

Al-Najjar (2008), Elinwa et al. (1993), Frimpong et al. (2003), Azhar et al. (2008), Okpala et al. (1988), and Nega (2008)

lyer et al. (2005)

Al-Juwaireh (1997) and Al-khaldi (1990)

Iyer et al. (2005), Al-khaldi (1990), Frimpong et al. (2003), and Okpala et al. (1988)

Al-Najjar (2008) and Nega (2008)

Al-Juwaireh (1997), Azhar et al. (2008), Frimpong et al. (2003), and Okpala et al. (1988)

Al-Juwaireh (1997), Nega (2008), and Azhar et al. (2008)

Iyer et al. (2005) and Al-khaldi (1990)

Al-Juwaireh (1997) and Azhar et al. (2008)

Nega (2008)

lyer et al. (2005) and Nega (2008)

Azhar et al. (2008)

Okpala et al. (1988)

Al-khaldi (1990)

Azhar et al. (2008)

Azhar et al. (2008)

is a good data consistency and agreement between consultants on the severity and frequency of the identified cost overrun factors. It also shows that the participants are highly agreed on the impact and frequency of the top affecting factors.

Based on the study findings, the following points are suggested in order to minimize and control cost overrun in building construction projects:

$>$ Training courses and workshops should be conducted to improve 


\begin{tabular}{|c|c|c|c|c|c|c|}
\hline \multirow{2}{*}{ Factor } & \multicolumn{3}{|c|}{ Severity responses } & \multicolumn{3}{|c|}{ Frequency responses } \\
\hline & $\bar{X}$ & Sn & CV (\%) & $\bar{X}$ & Sn & CV (\%) \\
\hline cost of insurance & 2.21 & 0.65 & 29.46 & 2.31 & 0.97 & 41.91 \\
\hline fraudulent practices and kickbacks & 2.74 & 1.10 & 40.00 & 2.45 & 0.77 & 31.55 \\
\hline level of competitors & 3.75 & 0.69 & 18.48 & 3.61 & 0.82 & 22.64 \\
\hline manipulation of suppliers & 3.85 & 0.63 & 16.32 & 3.03 & 0.86 & 28.28 \\
\hline transportation cost & 2.55 & 0.72 & 28.26 & 2.50 & 0.89 & 35.78 \\
\hline absence of construction-cost data & 2.93 & 0.80 & 27.18 & 2.93 & 0.80 & 27.18 \\
\hline additional work & 2.74 & 1.01 & 36.77 & 2.98 & 0.85 & 28.59 \\
\hline bureaucracy in tendering method & 3.17 & 0.95 & 29.87 & 2.45 & 0.87 & $35 \cdot 52$ \\
\hline contract management & 3.70 & 0.96 & 25.89 & 3.32 & 0.89 & 26.88 \\
\hline contractual procedure & 2.98 & 0.80 & 26.97 & 3.03 & 0.76 & 25.01 \\
\hline cost of labor & 2.98 & 0.64 & 21.38 & 2.88 & 0.74 & 25.51 \\
\hline cost of machinery & 2.74 & 0.85 & 31.00 & 2.36 & 0.71 & 30.20 \\
\hline currency exchange & 3.65 & 0.80 & 21.79 & 3.70 & 1.00 & 26.99 \\
\hline disputes os site & 3.17 & 0.86 & 27.08 & 2.79 & 0.71 & 25.48 \\
\hline duration of contract period & 3.41 & 0.83 & 24.24 & 3.13 & 0.81 & 26.00 \\
\hline economic instability & 4.04 & 0.76 & 18.93 & 3.41 & 1.00 & 29.36 \\
\hline effects of weather & 2.93 & 0.89 & 30.41 & 2.45 & 0.66 & 27.01 \\
\hline fluctuation of prices of materials & 4.09 & 0.60 & 14.78 & 3.89 & 0.77 & 19.66 \\
\hline frequent changes in design & 3.32 & 0.98 & 29.46 & 2.79 & 0.71 & 25.48 \\
\hline government policies & 2.74 & 0.94 & 34.26 & 2.40 & 0.98 & 40.63 \\
\hline high interest rates by bankers & 2.21 & 0.82 & 36.86 & 2.26 & 0.98 & 43.40 \\
\hline high machinary maintenace cost & 2.21 & 0.65 & 29.46 & 2.50 & 0.89 & 35.78 \\
\hline $\begin{array}{l}\text { inadequate production of raw materials by the } \\
\text { country }\end{array}$ & 3.46 & 0.99 & 28.67 & 2.60 & 0.93 & 36.01 \\
\hline inflationary pressure & 3.89 & 0.86 & 22.18 & 3.32 & 0.98 & 29.46 \\
\hline lack of adequate manpower & 3.22 & 0.90 & 28.01 & 2.55 & 0.82 & 32.33 \\
\hline lack of coordination between construction parties & 3.37 & 0.74 & 21.87 & 2.74 & 0.85 & 31.00 \\
\hline long period between design and time of tendering & 3.03 & 0.76 & 25.01 & 2.84 & 0.92 & 32.40 \\
\hline monopoly by supplier & 2.79 & 1.03 & 37.00 & 1.97 & 0.76 & 38.43 \\
\hline number of competitors & 3.65 & 0.74 & 20.37 & 3.65 & 0.74 & 20.37 \\
\hline number of projects going at the same time & 3.17 & 0.95 & 29.87 & 2.79 & 0.82 & 29.24 \\
\hline political situation & 4.38 & 0.71 & 16.16 & 3.85 & 0.63 & 16.32 \\
\hline poor financial control on site & 3.13 & 0.91 & 28.98 & 2.69 & 0.92 & $34 \cdot 35$ \\
\hline poor planning & 4.04 & 0.95 & 23.55 & 2.93 & 1.06 & 36.01 \\
\hline poor productivity & 2.93 & 0.80 & 27.18 & 2.84 & 0.87 & 30.83 \\
\hline previous experience of contract & 3.94 & 1.24 & 31.54 & 3.37 & 0.97 & 28.83 \\
\hline project financing & 3.80 & 0.72 & 18.96 & 3.41 & 0.78 & 22.78 \\
\hline project location & 3.27 & 0.85 & 26.07 & 2.64 & 0.71 & 26.91 \\
\hline relationship between managers and labors & 3.13 & 0.81 & 26.00 & 3.22 & 0.81 & 25.10 \\
\hline social and cultural impacts & 2.40 & 0.89 & 37.06 & 2.40 & 0.93 & 38.89 \\
\hline waste on site & 1.63 & 0.55 & 33.59 & 2.50 & 0.85 & 33.94 \\
\hline wrong estimation method & 3.27 & 0.90 & 27.46 & 2.93 & 0.89 & 30.41 \\
\hline
\end{tabular}

Table 12. Statistical analyses for severity and frequency responses 
managerial skills of project participants

Material prices and labor rates should be updated continuously.

Sufficient time should be given for preparing feasibility studies, planning, design, information documentation and tender submission. This helps avoiding or minimizing late changes

- Progress payment should be paid on time

More communication and coordination between project participants during all project phases.

Top management must react positively to political and environmental changes by means of managerial and financial policies

\section{References}

Ahmed, S., Azhar, S., Kappagantula, P., and Gollapudi, D. (2003). Delays in: A brief study of the Florida construction industry. Proceeding of the 39th Annual Conference of the Associated Schools of Construction. Clemson, South Carolina: Clemson University, Miami, USA.

Al-Juwairah, Y. (1997). Factors Affecting Construction Costs in Saudi Arabia. Master thesis, King Fahd University of Petroleum and Minerals, Dhahran, Saudi Arabia.

Al-Khaldi, Z. (1990). Factors Affecting the Accuracy of Construction Costs Estimating in Saudi Arabia. Master thesis, King Fahd University of Petroleum and Minerals, Dhahran, Saudi Arabia.

Al-Momani, A. (1996). Construction cost prediction for public school buildings in Jordan", Construction Management and Economics. 14: 311-317.

Al-Najjar, J. (2008). Factors influencing time and cost overruns on construction projects in the Gaza Strip. Master thesis, Islamic University, Gaza.

Al-Zarooni, S. and Abdou, A. (2000). Risk management in pre-design stage and its potential benefits for UAE public projects. Proceedings of the 28 th World Congress on Housing Challenges for the 21st Century, 15-19 April, Abu Dhabi, UAE.

Arditi, D., Akan, G., and Gurdamar, S. (1985). Cost Overruns in Public Projects. Journal of

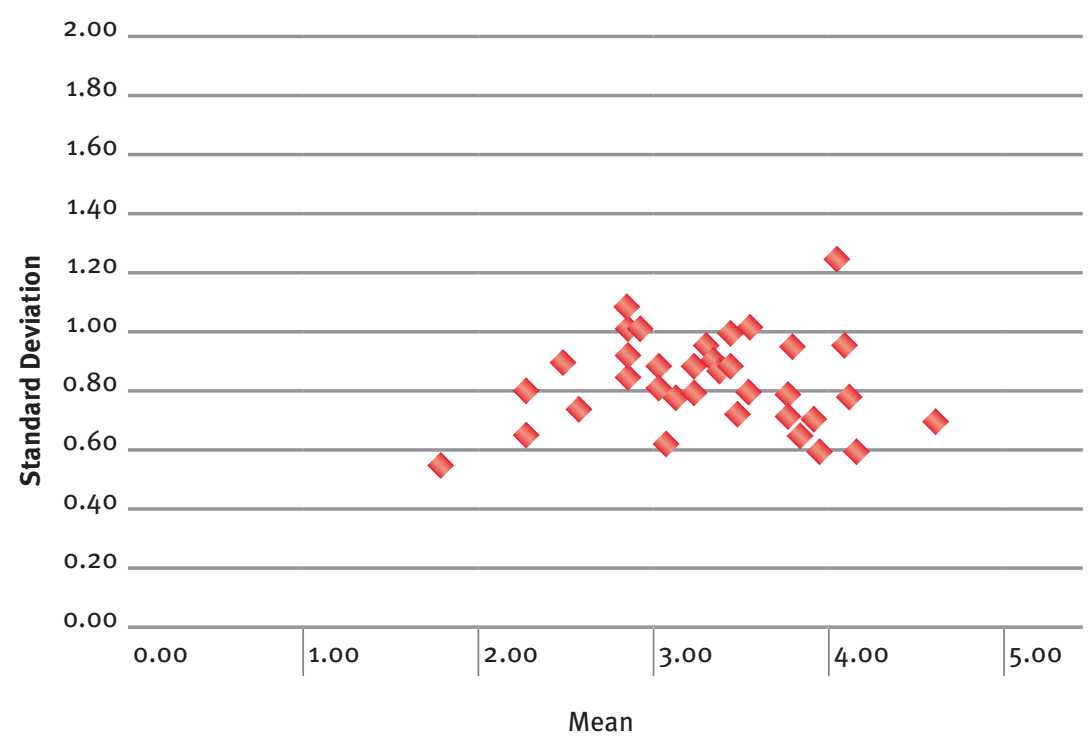

Figure 9. Factor mean vs. standard deviation for severity responses

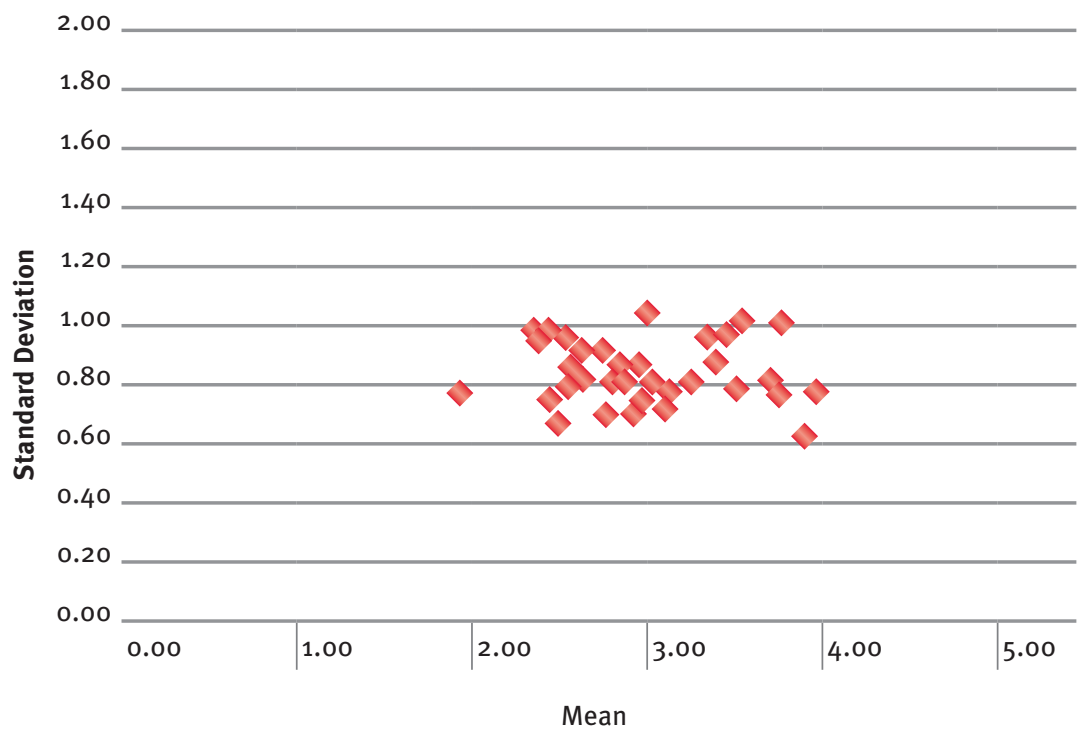

Figure 10. Factor mean vs. standard deviation for frequency responses

Project Management. 3(4):218-234.

Azhar, N., Farooqui, R., and Ahmed, S. (2008). Cost Overrun Factors In Construction Industry of Pakistan. Proceedings of the First International Conference on Construction in Developing Countries, Karachi, Pakistan.

Charoenngam,C. and Sriprasert, E. (2001). Assessment of cost control systems: a case study of Thai construction organizations. Engineering, Construction and Architectural Management. 8: 368-380.

Chitkara, K. (2004). Construction Project
Management, Planning, Scheduling, and Controlling. Tata McGraw Hill, 4th edition, India.

Elinwa, A. and Buba, S. (1993). Construction Cost Factors in Nigeria. Journal of Construction Engineering and Management. 119(4): 698-713.

Frimpong, Y., Oluwoye, J., and Crawford, L. (2003). Causes of delay and cost overruns in construction of groundwater projects in a developing countries; Ghana as a case study. International Journal of Project Management. 21: $321-326$. 


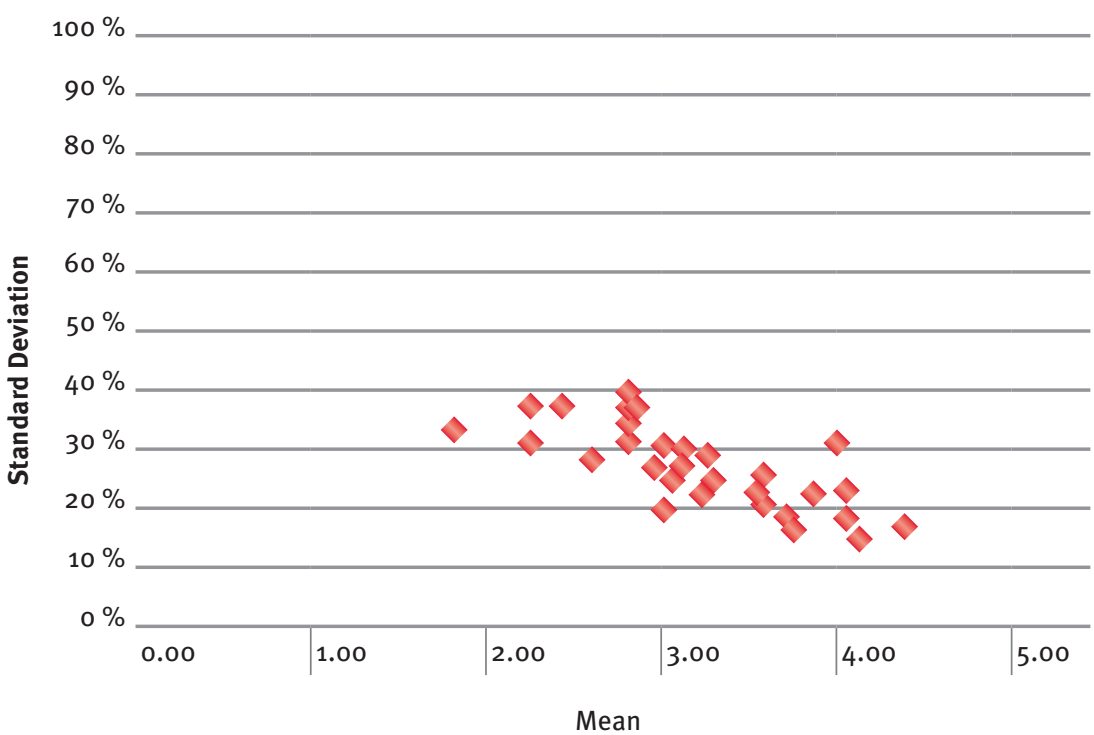

Figure 11. Factor mean vs. coefficient of variation for severity responses

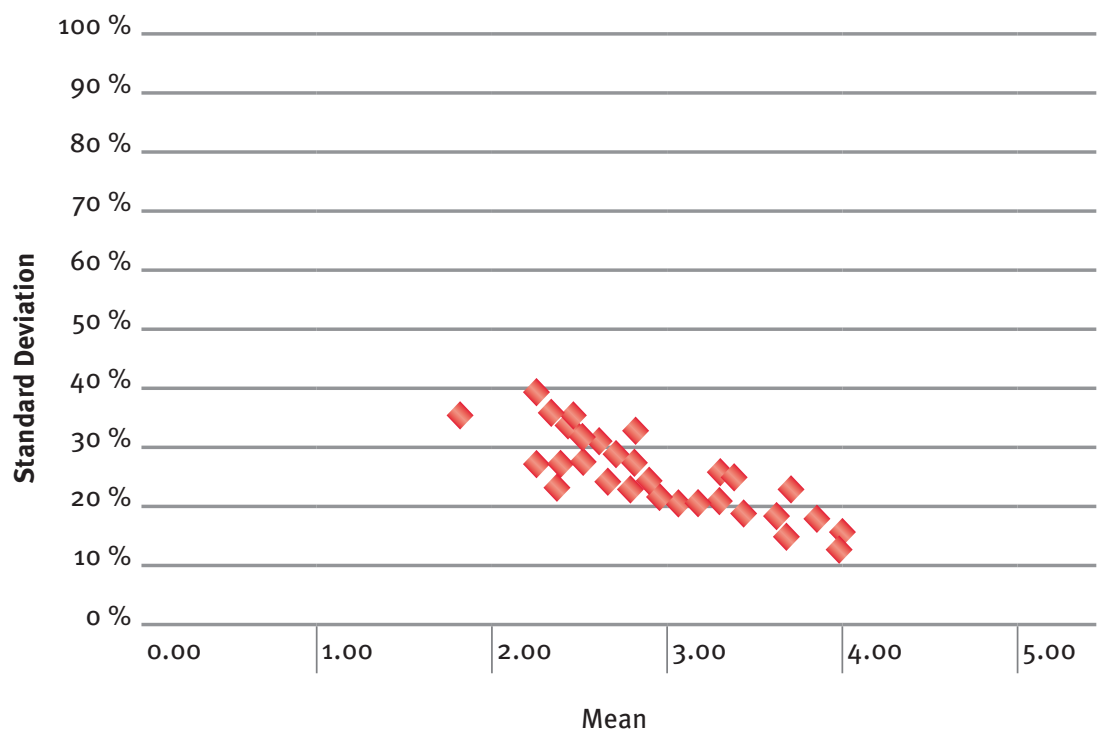

Figure 12. Factor mean vs. coefficient of variation for frequency responses
Iyer, K. and Jha, K. (2005). Factors affecting cost performance: evidence from Indian construction projects. International Journal of Project Management. 23(4): 283-295.

Kartam, N. and Kartam, S. (2001). Risk and its management in the Kuwaiti construction industry: a contractors' perspective. International Journal of Project Management. 19(6): 325-335.

Leibing, R. (2001). The Construction Industry: Process Players. Upper Saddle River, NJ: Prentice Hall.

Mahamid, I. and Bruland, A. (2012). "Cost deviation in road construction projects: The case of Palestine." Australasian Journal of Construction Economics and Building, 12(1), $58-71$.

MAP (2002). Survey of the Construction Services Industry. Unpublished mission report. The West Bank and Gaza.

Mbahu, J. and Nkado, R. (2004). Reducing Building Construction Costs: The Views of Consultants and Contractors. Proceedings of the International Construction Research Conference of the Royal Institution of Chartered Surveyors, Leeds Metropolitan University.

Nega, F. (2008). Causes and effects of cost overrun on public building construction projects in Ethiopia. Master thesis, Addis Ababa University, Addis Ababa, Ethiopia.

Odeck, J. and Skjeseth, T. (1995). Assessing Norwegian toll roads. Transportation Quarterly. 49(2): 89-98.

Okpala, D. and Aniekwu, A. (1988). Causes of High Costs of Construction in Nigeria. Journal of Construction Engineering and Management. 114(2): 233-244.

Palestinian Contractors Union. Personal comuunication, August 2010, Ramallah, the West Bank, Palestine.

The U.S. Federal Highway Administration Office of International Programs (2007). Guide to the risk assessment and allocation process in highway construction. Report, July, 2007. Retrieved from http://international.fhwa.dot. gov/riskassess/images/riskmatrix.cfm , $20^{\text {th }}$ of March, 2010.

UNRWA. 2006. Projects completion reports, UNRWA, Gaza.

Zainudeen, M., Kumari, G., and Seneviratne, T. (2008). Impact of Design Changes on Contractors' Cash Flow. Built-Environment Sri Lanka. 8(1): 2-10. 